\title{
PENGUATAN NILAI-NILAI KEAGAMAAN BAGI MASYARAKAT KORBAN BENCANA GEMPA DI KENAGARIAN TANDIKAT KECAMATAN PATAMUAN KABUPATEN PADANG PARIAMAN
}

\author{
Gazali \\ Fakultas Ushuluddin Adab dan Dakwah Institut Agama Islam Negeri (LAIN) Bukittinggi \\ e-mail:gazaliimam@gmail.com \\ Nofri Andy \\ Fakultas Ushuluddin Adab dan Dakwah Institut Agama Islam Negeri (LAIN) Bukittinggi \\ e-mail:nofry_andi@yahoo.co.id \\ DOI: bttp:/ / dx.doi.org/10.30983/islam_realitas.v3i2.403
}

Diterima: 14 November $2017 \quad$ Direvisi:29 Desember $2017 \quad$ Diterbitkan: 31 Desember 2017

\begin{abstract}
Nagari Tandikat is one of the Nagari in Padang Pariaman Regency that suffered severe impacts due to the earthquake of 30 September 2009. In the face of the earthquake, stoic attitude must be owned by earthquake victims as this will form a positive psychological condition (positive psychological functioning), which brings to the realization of psychological well being in a person especially religious values adopted because religion is able to create its own color in regulating the pattern of buman attitudes. More specifically, religion also wrestles with various problems of human life both socially and psychologically, the belief in god is able to give calm, not infrequently the religion is also used as a solution to the problems of the mind and not visible, related to pleasure, to suffering. By using the CBR approach, this research will conduct research-based devotion in the strengthening of religious values for the September 30th Quake Victims in Nagari Tandikat Padang Pariaman. From the research results revealed there are several strengthening programs that have been and are being done as a strengthening of religious values for the earthquake victims such as wirid yasinan, tablig akbar, annual commemoration and religious strengthening program.
\end{abstract}

Keywords: Strengthening V alues, Religion Value, Disaster Victim Handling

Abstrak
Nagari Tandikat merupakan salah satu Nagari di Kabupaten Padang Pariaman yang
mengalami dampak cukup parah akibat gempa bumi 30 September 2009. Dalam
menghadapi gempa, sikap tabah harus dimiliki oleh korban gempa karena hal ini akan
membentuk kondisi psikologis yang positif (positive psychological functioning), yang membawa
kepada terwujudnya kesejahteraan psikologis (psychological well being) dalam diri seseorang
terutama nilai-nilai agama yang dianut karena agama mampu menciptakan warna tersendiri
dalam mengatur pola sikap manusia. Lebih spesifik, agama juga bergelut dengan beragam
persoalan hidup manusia baik secara sosial maupun psikis, keyakinan terhadap tuhan mampu
memberi ketenangan, tidak jarang agama juga dijadikan sebagai solusi atas permasalahan-
permasalahan batin dan tidak terlihat, terkait kesenangan, hingga penderitaan. Dengan
menggunakan pendekatan CBR, penelitian ini akan melakukan penelitian berbasis pengabdian
dalam penguatan nilai-nilai agama bagi Korban Gempa 30 September di Nagari Tandikat
Padang Pariaman. Dari hasil penelitian tersebut diungkap ada beberapa program penguatan
yang telah dan tengah dilakukan sebagai penguatan nilai-nilai keagamaan bagi masyarakat
korban gempa yaitu wirid yasinan, tablig akbar, peringatan tahunan dan program penguatan
keagamaan.

Kata Kunci: Penguatan Nilai, Nilai Agama, Penanganan Korban Bencana

\section{Latar Belakang}

Sumatera Barat termasuk dalam provinsi yang mempunyai berbagai macam potensi bencana alam. Salah satu kabupaten di
Sumatera Barat yang pernah dilanda bencana alam yang cukup dahsyat adalah Kabupaten Padang Pariaman, yaitu bencana gempa bumi 7,6 SR pada tanggal 30 September 2009, yang 
banyak menimbulkan korban jiwa dan harta benda masyarakat. Selain itu kabupaten ini juga diprediksikan akan terkena dampak bencana tsunami dari Mentawai.

Nagari Tandikat merupakan salah satu Nagari di Kabupaten Padang Pariaman yang mengalami dampak cukup parah akibat gempa bumi 30 September 2009, yaitu hampir $90 \%$ bangunan rusak berat, 260 orang meninggal dunia dan 79 orang dinyatakan hilang, hal ini terjadi karena struktur tanah Nagari Tandikat termasuk dalam jenis tanah aluvial, yaitu tanah dari abu letusan gunung yang sangat lembur dan mudah terban atau longsor.

Keadaan ini masih meninggalkan kesan yang mendalam bagi masyarakat setempat hingga saat ini, lebih dari 300 warga terkubur hidup-hidup setelah bukit yang ada di sekitar perkampungan longsor. Ada tiga korong atau setingkat RW yang dilanda longsor, di antaranya korong Cumanak, korong Pulau Air dan Korong Lubuk Laweh.

Setelah tim pengabdian masyarakat IAIN Bukittinggi yang diketuai oleh Gazali melakukan asesmen terhadap lokasi ternyata lokasi longsor tersebut telah direlokasi dan masyarakat telah pindah ke tempat yang lain dengan bantuan Pemda Kabupaten Padang Pariaman atau dengan bantuan masyarakat lainnya. Masyarakat yang terkena bencana telah pindah ke perumahan cumanak dan perumahan Kampung Jambak di daerah Tandikat Induk. Tim juga melakukan audiensi dengan petugas KUA yang membidangi keagamaan dan mereka menyatakan bahwa trauma yang dialami oleh warga sudah berkurang karena telah berlangsung tujuh tahun, namun peringatan mengenai peristiwa gempa tetap berlangsung dan telah menjadi agenda Pemerintahan Kabupaten.

Ada beberapa kondisi yang menyebabkan terjadinya perubahan dalam kehidupan sosial masyarakat, seperti kondisi ekonomi, teknologi dan geografis. Hal ini terjadi tidak saja disebabkan oleh faktor internal namun juga disebabkan oleh faktor eksternal. Seperti terjadinya bencana alam yang dapat merubah kehidupan sosial seseorang secara drastis. Begitu juga dengan kejadian gempa 30 september atau dikenal oleh masyarakat Tandikat dengan peringatan G 30 S. Dari fenomena gempa yang dijelaskan oleh informan yang tim pengabdian kunjungi adalah masih terasanya kesedihan yang mendalam bagi masyarakat ketika mengingat kejadian tersebut karena keluarga mereka banyak yang tertimbun dalam longsor tersebut. Bencana alam yang menimpa suatu daerah dapat mengakibatkan terganggunya ketenangan dan pola hidup masyarakat. Dalam hal-hal tertentu bencana alam juga dapat menghancurkan harapan hidup anggota masyarakat. Mereka kehilangan sebagian atau semua kekayaan yang dimiliki baik berbentuk benda hidup, seperti anggota keluarga, ternak, dan tanaman maupun benda mati, seperti rumah, perkarangan, ladang, dan sawah tempat mereka menggantungkan hidup.

Bencana sebagai "ranah" untuk memahami lebih mendasar konstruksi masyarakat, yang tidak hanya berdampak pada kerusakan dan kerugian semata. Dengan memahami suatu bencana manusia akan terbebaskan dari perangkap normalitas. Ketika bencana terjadi pemahaman masyarakat tidak seharusnya terhenti sebatas sebuah peristiwa saja. Karena dengan melihat bencana sebagai sebuah konteks, proses penanggulangan bencana (disaster mitigation) dapat dilakukan secara normal oleh semua pihak tidak terkecuali oleh korban bencana itu sendiri. ${ }^{1}$

${ }^{1}$ Lihat, Kyoo-Man Ha, “The Role of Religious Beliefs and Institutions in Disaster Management: A Case Study", Religions, Vol. 6, 2015, h. 1314-1329. Bandingkan dengan J. C. Gaillard and P. Texier, "Religions, Natural Hazards, and Disasters: An Introduction", Religion, Vol. 40 , 2010, h. 81-84. 
Minimnya pengetahuan masyarakat tentang mitigasi bencana diduga menjadi salah satu penyebab timbulnya korban jiwa pada saat bencana. Hal ini disebabkan oleh pemahaman masyarakat tentang mitigasi bencana yang rendah, sehingga mereka tidak siap dalam meghadapi bencana tersebut. Mengingat banyaknya ancaman bencana yang diprediksikan akan melanda kabupaten Padang Pariaman, maka diperlukan berbagai usaha untuk melakukan mitigasi bencana, salah satunya adalah memberikan pengetahuan kepada masyarakat tentang mitigasi bencana.

Angka kerugian yang ditanggung para korban sudah tidak terhitung, jatuhnya korban baik yang meninggal, cacat fisik sementara dan permanen marupakan harga mahal yang tidak terbayar. Hal lain yang juga berkaitan secara langsung terhadap korban adalah dampak sosial berkepanjangan yang ditimbulkan akibat bencana gempa tersebut. Imbas dari gempa bumi bukan semata kerugian material dan hilangnya ribuan nyawa, dampak sosial pasca gempa dapat dicermati melalui respon masyarakat dari berbagai kalangan, yaitu maraknya aksi peduli terhadap korban bencana gempa dan aksi-aksi lain dari berbagai masyarakat dengan motif yang sama, aksi peduli korban gempa.

Tanda-tanda kebangkitan dan pulihnya para korban setelah gempa dapat diverifikasi melalui respon positif dan optimisme mereka setelah gempa. Di belakang, para korban mempunyai warisan kehidupan yang masih tersisa, ungkapan optimisme diwujudkan dengan mengais aset-aset tersisa, sementara gempa itu sendiri dimaknai sebagai perjalanan bukan sebagai penghancuran kehidupan. Seiring dengan besarnya tekanan para korban, tindakan bijaksana atau arif yang mengarah pada pemulihan adalah membangun jaringan relasi sumber daya manusia baik para relawan dan para korban dalam bentuk kesadaran dengan membangkitkan spiritualitas dalam berbagai bentuk hingga kehidupan para korban dapat berjalan secara normal.

Gempa bumi yang menimpa Nagari Tandikat menyimpan duka yang mendalam bagi masyarakat karena di samping memakan korban jiwa juga menghilangkan harta benda. Dalam pengabdian ini, tim mengajukan beberapa alasan pemilihan dampingan, di antaranya; a) Daerah tempat tinggal masyarakat tidak dapat dihuni kembali sehingga mereka direlokasi ke tempat yang lain. Maka hal ini memicu trauma yang mendalam ketika mereka mengunjungi tempat tersebut, mereka berpandangan bahwa harta benda yang mereka miliki tidak dapat digunakan lagi dan dijadikan sebagai kuburan massal; b) Minimnya perhatian pemerintah terhadap korban bencana sehingga mereka berpencar-pencar untuk tinggal dan pergi merantau karena kehilangan keluarga, pekerjaan dan harta benda; c) Ketidakjelasan tanggung jawab terhadap penanganan anakanak korban gempa, sehingga seringkali hal ini diserahkan kepada keluarga terdekat tanpa ada solusi selanjutnya; d) Minimnya sosialisasi keagamaan sebagai wadah untuk memperbaiki mental dan mendekatkan diri kepada Allah swt. Hal ini dapat diterapkan dengan penyuluhan, ceramah agama atau Taman Pendidikan al-Qur'an bagi anak-anak korban gempa

Setelah tim mengadakan asesmen terhadap korban dan bekas lokasi gempa, daerah tersebut tidak dapat dihuni kembali dan dijadikan sebagai kuburan massal. Daerah ini sangat bahaya apabila didirikan bangunan karena keselamatan tidak akan terjamin. Menurut penuturan Sekretaris Nagari Tandikat, Indra Duniana warga masih bersikeras untuk kembali tinggal di sana karena mereka menganggap hanya itulah harta satusatunya milik mereka dan apabila berharap kepada bantuan hanya sesaat. Hal ini tetap dilarang oleh pihak pemerintahan setempat 
dan lokasi ini dianggap sebagai zona merah yang harus dihindari.

Ismail selaku wali korong lubuk laweh menyatakan bahwa masyarakat masih trauma apabila mengingat kejadian dan keluaga yang hilang. Ketika wawancara pun setiap informan yang dimintai keterangan oleh tim selalu menguraikan air mata, hal ini mengingat bahwa mereka berada di lokasi pada saat kejadian. Sebagian masyarakat tinggal di rumah hunian sementara yang terkesan tidak layak dan dapat rusak sewaktu-waktu. Sebagian masyarakat korban gempa juga ada yang mengontrak di dekat pasar Tandikat sambil menunggu realisasi bantuan dari pemerintah daerah.

Kejadian gempa ini juga memisahkan warga yang dahulunya hidup sekampung menjadi berpencar-pencar. Dari hasil wawancara tim dengan informan, masyarakat korban gempa juga ada yang merantau karena pekerjaan yang sebelumnya bertani sudah tidak ada lagi.

Yang menjadi masalah penting dalam ini adalah minimnya penyuluhan-penyuluhan keagamaan yang dilakukan oleh pemerintah daerah. Pembangunan fisik hendaknya dibarengi dengan pembangunan mental karena akan berpengaruh kepada perilaku dan paradigma korban dalam menerima musibah.

Bencana alam adalah suatu peristiwa yang disebabkan oleh alam atau karena ulah tangan manusia yang dapat terjadi secara tibatiba atau perlahan, yang menyebakan hilangnya jiwa manusia, kerusakan harta benda dan lingkungan serta melampaui kemapuan manusia dalam menanggulanginya ${ }^{2}$. Dari pengertian lain, bencana adalah peristiwa atau serangkaian peristiwa yang menyebabkan gangguan serius pada masyarakat sehingga menyebabkan korban jiwa serta kerugian yang

2 Tim IDEP, Panduan Umum Penanggulangan Bencana Berbasis Masyarakat (Bali, Yayasan IDEP, 2007), h. 31 . meluas pada kehidupan manusia baik dari segi materi, ekonomi maupun lingkungan dan melampaui kemampuan masyarakat tersebut untuk mengatasi menggunakan sumber daya yang mereka miliki. Dari pengertian di atas, bencana merupakan sebuah peristiwa yang terjadi karena bertemunya ancaman dari luar terhadap kehidupan manusia dengan kerentanan, yaitu kondisi yang melemahkan masyarakat untuk menangani bencana ${ }^{3}$. Singkatnya, Steinberg mengatakan bahwa ketika ancaman berdampak merugikan manusia dan lingkungan, dan tidak adanya kemampuan masyarakat untuk menanggulanginya maka peristiwa itu disebut dengan bencana. ${ }^{4}$

Dalam tulisan ini penulis akan menjelaskan tentang penguatan nilai-nilai keagamaan dalam program penanggulangan bencana gempa di Nagari Tandikat Padang Pariaman. Kegiatan yang awalnya berasal dari program pengabdian ini bekerja sama dengan lembaga-lembaga pemerintahan setempat, seperti Kantor Urusan Agama Kecamatan Patamuan, Wali Nagari Tandikat Utara, wali korong setempat serta segenap masyarakat yang ada untuk menampung aspirasi dari mereka, sehingga kegiatan ini sesuai dengan apa yang dibutuhkan oleh masyarakat. Tim pengabdian juga ingin menjadikan IAIN sebagai lembaga terdepan yang concern terhadap korban bencana sehingga dapat membantu untuk memulihkan traimatik masyarakat korban gempa di kenagarian Tandikat.

\section{Bencana Alam dan Fenomenanya}

Bencana alam adalah suatu peristiwa yang disebabkan oleh alam atau karena ulah tangan manusia yang dapat terjadi secara tiba-

${ }^{3}$ Tim Penyusun, Hasil Simposium Nasional Kedua Manajemen Resiko Bencana Berbasis Masyarakat Mencari Jadi Diri Bangsa Indonesia, Hotel Sofyani, Cikini Jakarta, 12-13 April 2006

4 Theodore Steinberg, "What Is a Natural Disaster?," Literature and Medicine, Vol. 15, No. 1, 1996, h. 34 . 
tiba atau perlahan, yang menyebakan hilangnya jiwa manusia, kerusakan harta benda dan lingkungan serta melampaui kemapuan manusia dalam menanggulanginya ${ }^{5}$. Dari pengertian lain, bencana adalah peristiwa atau serangkaian peristiwa yang menyebabkan gangguan serius pada masyarakat sehingga menyebabkan korban jiwa serta kerugian yang meluas pada kehidupan manusia baik dari segi materi, ekonomi maupun lingkungan dan melampaui kemampuan masyarakat tersebut untuk mengatasi menggunakan sumber daya yang mereka miliki. Dari pengertian di atas, bencana merupakan sebuah peristiwa yang terjadi karena bertemunya ancaman dari luar terhadap kehidupan manusia dengan kerentanan, yaitu kondisi yang melemahkan masyarakat untuk menangani bencana ${ }^{6}$. Singkatnya ketika ancaman berdampak merugikan manusia dan lingkungan, dan tidak adanya kemampuan masyarakat untuk menanggulanginya maka peristiwa itu disebut dengan bencana.

Berdasarkan penyebab bahayanya, bencana dapat dikategorikan menjadi tiga, yaitu bencana alam, bencana sosial dan bencana campuran. Bencana alam disebabkan oleh kejadian-kejadian alamiah seperti gempa bumi, tsunami, gunung api, dan angin topan. Bencana sosial atau bencana buatan manusia, yaitu hasil dari tindakan langsung maupun tidak langsung manusia seperti perang, konflik sosial, terorisme dan kegagalan teknologi. Bencana dapat terjadi karena alam dan manusia sekaligus yang dikenal sebagai bencana campuran atau kompleks, seperti banjir dan kekeringan. Jika dilihat dari tempo kejadiannya, ancaman dapat terjadi secara mendadak, berangsur-angsur atau musiman. Contoh ancaman yang terjadi secara mendadak

5 Tim IDEP, Panduan Umum Penanggulangan Bencana Berbasis Masyarakat....., h. 32.

${ }^{6}$ Tim Penyusun, Hasil Simposium Nasional Kedua Manajemen Resiko Bencana Berbasis Masyarakat Mencari Jadi Diri Bangsa Indonesia......, h. 21. adalah gempa bumi, tsunami, dan banjir bandang, ancaman yang berlangsung secara perlahan-lahan atau berangsur-angsur adalah banjir genangan, rayapan, kekeringan dan ancaman yang terjadi musiman adalah banjir bandang (di musim hujan), kekeringan (di musim kemarau) dan suhu dingin.

Jadi, penyebab bencana alam dapat digolongkan menjadi 2 (dua), yaitu bencana yang timbul bukan akibat aktivitas manusia dan bencana yang timbul akibat aktivitas manusia langsung. Contoh klasik untuk jenis yang pertama misalnya gempa bumi. Gempa bumi terjadi bukanlah akibat aktivitas manusia secara langsung, tetapi merupakan proses alam yang memang akan terus terjadi demi keseimbangan bumi (alam) itu sendiri. Jenis bencana yang kedua dapat kita ambil contoh klasik: banjir. Banjir yang sering melanda Indonesia merupakan dampak dari ulah manusia yang tidak bersahabat dengan alam. ${ }^{8}$

\section{Agama dan Penanggulangan Bencana}

Proses penanggulangan korban bencana tidak selalu terkonsentrasi pada bantuan secara fisik semata. Aspek non fisik dalam konteks penanggulangan bencana sangat penting atau bahkan lebih penting dari penanganan atau luka-luka secara fisik. Dalam hal ini penting untuk mendefenisikan tentang kerangka pikir yang digunakan dan relavansinya atas pembahasan-pembahasan berikutnya. Secara sosiologis, agama mampu menciptakan warna tersendiri dalam mengatur pola sikap manusia. Lebih spesifik, agama juga bergelut dengan beragam persoalan hidup manusia baik secara sosial maupun psikis, keyakinan terhadap tuhan mampu memberi ketenangan, tidak jarang agama juga dijadikan sebagai solusi atas

${ }^{7}$ Tim Penyusun, Panduan Pengenalan Karakteristike Bencana dan Upaya Mitigasinya di Indonesia (Jakarta: Tim Bakornas BP, 2007), h. 20.

${ }^{8}$ Akhand Pratibha and Akhand Archna, "At the Whim of Nature "Natural Disasters": Causes and Prevention", Social Issues and Environmental Problems, Vol. 3, No. 9, 2015, h. 1-4. 
permasalahan-permasalahan batin dan tidak terlihat, terkait kesenangan, hingga penderitaan.

Menurut Jalaluddin, musibah bencana mengakibatkan korbannya mengalami penderitaan lahir dan batin. Melalui musibah itu juga, korban bencana dapat menemukan hikmah dan nilai-nilai positif yang terkandung di dalamnya. Musibah ditafsirkan dengan beragam tafsiran yang berkaitan dengan ajaran-ajaran agama itu sendiri'. Dalam konteks bencana, agama menjadi sumber motivasi korban untuk melakukan tindakan-tindakan positif. Lebih lanjut Jalaluddin mengomentari, dalam menghadapi musibah, korban dapat terlihat menjadi lebih tabah, dan lebih mudah menetralisir kegoncangan dalam batinnya. Sesuatu yang lebih penting adalah munculnya kesadaran korban untuk merealisasikan upacara-upacara keagamaan berupa do'a, baik secara individu maupun secara berkelompok $^{10}$. Upacara keagamaan dalam masyarakat Indonesia sudah menjadi bagian dari kebudayaan, permohonan atau do'a-do'a bersama kerap dijumpai melalui pengajianpengajian, terutama dalam masyarakat Islam.

Agama tampil sebagai usaha teoritis dari individu-individu mamahami dunia, membina ummat beragama dalam menjalankan peran konstruktif membangun tatanan kehidupan dan tak luput pula terhadap alam dan respon terhadap timbulnya suatu becana alam ${ }^{11}$.

Bentuk kehidupan bersama di mana anggota-anggotanya diikat oleh hubungan batin tampak jelas juga pada realita masyarakat agama, keyakinan terhadap agama memberi kekuatan batin dalam segala macam

9 Jalaluddin, Psikologi Agama," Memahami Perilaku Keagamaan Dengan Mengaplikasikan Prinsip-Prinsip Psikologi” (PT. RajaGrafindo Persada, 2007), h. 173.

${ }^{10}$ Jalaluddin, Psikologi Agama....., h.175.

${ }^{11}$ Abdul Kabir Hussain Solihu, "Making Sense of Natural Disasters: An Islamic Hermeneutics of Malevolent Phenomena in Nature and Its Implication for Sustainable Development", The American Journal of Islamic Social Sciences, Vol. 24, No. 1, 2007, h. 46-72. persatuan dan perjuangan ${ }^{12}$. Secara sosiologis, agama berfungsi sebagai institusi pengingat terhadap suatu tatanan sosial melalui kesadaran-kesadaran subyektif (internal) dan secara sosial dengan kesadaran- kesadaran obyektif (eksternal) ${ }^{13}$. Kesadaran subyektif adalah kesadaran batin yang didorong oleh semangat-semangat keagamaan. Peran sosial agama adalah mempersatukan anggota-anggota masyarakat dalam kewajiban-kewajiban sosial yang membantu mempersatukan masyarakat.

\section{Nilai Agama dalam Penanggulangan Bencana}

Indonesia kembali menangis dengan gempa yang terjadi di Yogyakarta dan Jawa Tengah baru-baru ini. Lebih dari lima ribu nyawa melayang dan ribuan lainnya mengalami luka-luka. Mereka bukan hanya kehilangan jiwa dan benda-benda/material lainnya, namun juga menyisakan kepiluan, kebalauan, dan kepanikan yang begitu mendalam. Derita itu tentu akan membawa trauma tersendiri jika tanpa disikapi dengan kedewasaan berfikir. Maka melewati kejadian besar seperti itu, chaos biasanya diikuti dengan semacam aktifitas penenangan jiwa (soul searching), yang bisa membawa kita kepada iman yang lebih kuat, atau justru krisis teologis yang mengguncang.

Secara material, bencana itu sudah pasti akan menyedot energi dan materi yang demikian banyak dan tak pernah direncanakan sebelumnya. Semuanya harus ditangani secara darurat, termasuk merehabilitasinya. Padahal, kalau saja peristiwa bencana tidak terjadi, segala pembiayaan itu bisa digunakan untuk secara perlahan melakukan perbaikan kondisi sosial dan ekonomi di daerah lain yang tertinggal. Tapi apa boleh buat, solidaritas kita sebangsa dan setanah air memang harus diwujudkan dengan kepedulian untuk

12 Hasan Sadily, Sosiologi Untuk Masyarakat Indonesia (Jakarta: PT. Rineka Cipta,1993), h.21.

13 Peter L. Berger, Langit Suci, Agama Sebagai Realitas Sosial (Jakarta: LP3ES, 1991), h. 20. 
mengatasi masalah bersama, termasuk berkorban untuk membantu saudara-saudara yang terkena musibah.

Bencana alam dan berbagai bentuk kecelakaan yang membawa korban jiwa manusia dan materi memang sering berada di luar kendali dan jangkauan pemikiran manusia biasa. Terbukti, fokus utama yang menjadi sorotan belakangan ini adalah meletusnya gunung Merapi. Namun, fakta bicara lain bahwa ada kekuatan lain "di atas sana" yang menghendaki terjadinya gempa di kedua wilayah itu. Manusia hanya bisa menafsir atau mereka-reka berdasarkan kemampuan ilmu pengetahuan dengan segala kenisbiannya.

Tindakan-tindakan moral seperti pengiriman bantuan, baik medis, makanan, maupun pakaian merupakan asas-asas nilai yang meneguhnya kita sebagai manusia bermoral. Hal ini menunjukkan bahwa kita berkewajiban untuk menjunjung tindakantindakan suci tersebut yang secara esensial berguna buat diri kita sendiri dan juga orang lain. Di sinilah nilai-nilai moral mendapatkan ruang kehadirannya.

Berdasarkan noktah di atas, manakala tujuan hidup tertinggi manusia adalah kedekatan diri pada Tuhan, maka suatu tindakan bernilai moral bilamana mendatangkan kedekatan Ilahi seperti mengirimkan bantuan kepada para korban gempa. Tindakan itu tentu menjadi prinsip nilai-nilai moral tanpa harus mempertanyakan komentar agama. Sebab, baiknya keadilan dan buruknya kezaliman sudah bisa diukur dengan pertimbangan akal sebagai anugerah tertinggi yang Tuhan berikan kepada kita. Dengan demikian, komitmen untuk berbagi bersama akan terwujud. ${ }^{14}$

Peristiwa bencana alam seperti gempa bumi, banjir, tanah longsor, hingga tsunami

${ }^{14}$ D. K. Chester, "Theology and Disaster Studies: The Need for Dialogue", Journal of Volcanology and Geothermal Research, Vol. 146, No. 4, 2005, h. 319328. yang terjadi di tanah air telah banyak mengundang reaksi masyarakat. Di antaranya ada yang secara langsung melakukan aksi di lapangan dengan membantu memulihkan situasi, namun ada juga yang mengekspresikannya melalui karya tulis dengan topik yang beragam. Sejauh ini belum ada baik skripsi maupun karya tulis lain yang membahas secara khusus mengenai agama sebagai instrumen rehabilitas traumatik korban bencana gempa.

Sebuah buku yang berjudul "Gempa Bumi: Ciri dan Cara Menanggulanginya" yang ditulis oleh Tiar Prasetya, lebih banyak mengulas secara kronologis gempa bumi dan cara menanggulanginya. Walau demikian buku ini sebenarnya besar kontribusinya bagi para relawan bencana khususnya dan masyarakat Indonesia pada umumnya, di dalamnya terdapat penjelasan secara geografis kepulauan negara Indonesia yang terletak pada pertemuan tiga lempeng utama yaitu lempeng Hindia atau Indo-Australia di sebeleh selatan yang bergerak relatif ke utara-timur dengan pergerakan sekitar $7 \mathrm{~cm} /$ tahun, lempeng Eurasia di utara yang bergerak relatif ke selatan dengan pergerakan dengan pergerakan sekitar $9 \mathrm{~cm} /$ tahun dan lempeng Pasifik di timur yang bergerak relatif ke barat dengan pergerakan 11 $\mathrm{cm} /$ tahun. Lempeng Indo-Australia yang berada di bawah Samudera Hindia menukik masuk ke bagian bawah lempeng benua Eurasia. Dengan letak geografis yang demikian kepulauan Indonesia merupakan daerah yang mempunyai aktivitas gempa bumi cukup tinggi $1^{15}$. Buku ini sangat relevan sekali untuk menyoroti aktivitas relawan di lokasi bencana selain itu akan menghantarkan pembaca pada pemahaman secara ilmiah seputar bencana gempa dan bencana alam lain seperti yang telah terjadi.

${ }^{15}$ Tiar Prasetya (ed), Gempa Bumi: Ciri dan Cara Menanggulanginya (Yogyakarta: Gita Nagari, 2006), h. 12. 
Karya lain yang secara langsung menyoroti peristiwa bencana alam yang disampaikan melalui sebuah pidato yang berjudul Dialektika Nature, Kultur Dan Struktur: Analisis Konteks, Proses dan Ranah dalam Konstruksi Bencana yang disampaikan Irwan Abdullah juga menyinggung tentang hubungan timbal balik antara manusia dengan alam, hingga kemunculan suatu bencana sebagai konsekwensi atas kecendrungan eksploitatif manusia, perubahan sosial akibat intervensi manusia setelah gempa. Dijelaskan pula bahwa perubahan cepat akan terjadi pada struktur dan sistem sosial masyarakat setelah gempa. Pada kondisi demikian, berbagai kemungkinan dan akibat negatif dapat terjadi, khususnya pada saat banyak agen terlibat dalam rekonstruksi yang menyebabkan sesuatu yang sangat asing dan baru muncul dalam suatu masyarakat secara tiba-tiba yang kemudian menyebabkan stres dan merusak tatanan sosial ${ }^{16}$.

Sebuah buku yang ditulis melalui refleksi dan pengalaman panjang oleh L. Don \& Florence Leet setebal 298 halaman, mengulas secara ilmiah penyebab terjadinya gempa bumi dari mulai proses, tanda-tanda serta mengantisipasinya. Dalam buku ini dilengkapi pula deretan panjang peristiwa-peristiwa bencana gempa dalam skala besar yang merenggut banyak korban nyawa manusia. Kehadiran buku tersebut dimaksudkan agar para pembaca memiliki pengetahuan perihal gempa bumi sebagai upaya untuk memperkecil resiko-resiko yang ditimbulkannya.

Salah satu sub bahasan dari rangkain penjelasan dalam buku ini adalah mengenai kerusakan terparah akan dialami jika struktural bangunan rumah tidak dibuat dari material yang kokoh dan tidak menggunakan perekat dalam setiap sisi serta dipaparka pula beberapa

16 Irwan Abdullah, "Dialektika Nature, Kultur dan Struktur: Analisis Konteks, Proses dan Ranah Dalam Konstruksi Bencana", Makalah disampaikan dalam Pidato Pengukuhan Guru Besar Antropologi di UGM Tanggal 13 Nov 2006, h. 10. contoh pengalaman masyarakat dibelahan dunia yang menderita kerusakan mengerikan akibat manggunakan material bangunan yang tidak memenuhi prasyarat ${ }^{17}$.

Dalam konteks Sumatera Barat, Syafwan Rozi dan telah melakukan riset tentang penanggulangan bencana berbasis budaya lokal. Kajian tersebut menemukan bahwa penanggulangan bencana berbasis budaya lokal merupakan upaya untuk mengoptimalkan potensi sosial dan nilai-nilai lokal yang dimiliki masyarakat untuk memudahkan proses penanganan bencana alam. ${ }^{18}$

Perbedaan karya tulisan di atas dengan tulisan pada penelitian ini adalah pemulihan kondisi mental korban pasca bencana dengan menggunakan kesamaan agama sebagai bentuk model sekaligus sebagai respon terhadap kondisi sosial para korban. Pemahaman sederhana dari penulis mengapa agama dijadikan sebagai instrumen pemulihan kondisi mental para korban tidak lain karena agama itu sendiri dan pergumulannya dengan dinamika kehidupan, alasan ini menjadi salah satu faktor mengapa penulis merumuskannya menjadi unsur tema penelitian. Kemudian berlanjut pada pembahasan-pembahasan dan yang tidak kalah penting adalah bagaimana respon masyarakat atas usaha-usaha para relawan baik secara fisik maupun lainnya, sebagai kelengkapan pembahasan dapat diketahui pula apakah para relawan telah melakukan peran konstruktif, terutama rehabilitasi mental masyarakat korban bencana melalui model tidakan yang dilakukan.

17 L. Don \& Florence Leet, Gempa Bumi, Penjelasan Ilmiah \& Sederhana, "Proses, Tanda- Tanda Akan Terjadinya, Serta Antisipasi Dampak”" (Yogyakarta: Kreasi Wacana, 2006), h. 21.

18 Syafwan Rozi, "Local Wisdom and Natural Disaster in West Sumatera", El-Harakah, Vol. 19, No. 1 (2017): 1-19. Lihat juga Nusyirwan Effendi, "Bencana: Pengalaman dan Nilai Budaya Orang Minangkabau", Jurnal Masyarakat Indonesia LIPI, Vol. 2, No. 2, 2007, h. 200-210.
Penguatan Nilai-nilai.......... 


\section{Kehidupan Sosial Keagamaan Masyarakat Tandikat}

Penduduk Nagari Tandikat berdasarkan data dari kantor walinagari tahun 2008 tercatat sebanyak 10.595 jiwa. Penduduk laki-laki terdiri dari 5.158 jiwa sedangkan sedangkan jumlah perempuan sebanyak 5.437 jiwa. Paska gempa pada tanggal 30 September 2009, yaitu Jorong Lubuak Laweh, Cumanak dan gunung Tigo tertimbun longsor yang mengakibatkan banyak yang meninggal dunia sampai sekarang ini data jumlah penduduk belum terakomodasi seluruhnya, diduga terjadi pengurangan jumlah penduduk pada tahun 2010.

Masyarakat Nagari Tandikat sebagian besar memiliki pekerjaan sebagai petani. Hal ini disebabkan kondisi tanahnya yang subur dan sangat cocok sebagai daerah agrikultur. Selain sebagai petani, masyarakat Tandikat juga bergerak di bidang peternakan, seperti beternak ayam, kerbau dan sapi, jasa, perkebunan kelapa, kakao, pinang, dan cengkeh. Selain sub sektor pertanian, perkebunan dan peternakan juga ada sektor industri kecil dan sedang yang juga mampu menopang perekonomian penduduk, seperti jenis usaha kerupuk kulit, jenis usaha pembuatan roti.

Selain usaha-usaha yang telah disebutkan, masyarakat Tandikat sebagian juga bekerja di sektor perdagangan, transportasi, dan jasa. Di sektor perdagangan sebagian penduduk membuka warung kecil-kecilan yang menjual barang kebutuhan sehari-hari (sembako). Hal ini cukup membantu masyarakat di sekitarnya jika tidak bisa berbelanja ke pasar.

Penduduk Nagari Tandikat seluruhnya beragama Islam. Agama Islam mereka anut secara turun temurun. Agama bagi masyarakat Nagari Tandikat memiliki peranan yang sangat penting dalam menjalani kehidupan bermasyarakat. Setiap tindakan yang dilakukan oleh masyarakat, baik itu acara pesta maupun acara duka selalu diawali dengan doa-doa khusus, seperti yang dilakukan pada upacara kematian.

Masyarakat Tandikat sebagian besar penganut Tarekat Syatariah. Di Nagari ini terdapat pondok pesantren yang anak didiknya tidak hanya berasal dari daerah tersebut, tetapi juga berasal dari luar daerah seperti dari Agam, Batusangkar, Padang Panjang dan daerah lainnya. Sarana-sarana ibadah yang ada di Nagari Tandikat adalah masjid, mushalla, dan surau. Masjid tercatat sebanyak 12 (dua belas) buah sedangkan mushalla dan surau sebanyak 11 (sebelas) buah. Kegiatan keagamaan yang biasa dilakukan masyarakat Nagari Tandikat adalah Jum'atan, pengajian umum, pengajian ibu-ibu, pengajian anak-anak, pengajian remaja, yasinan, dan peringatan hari besar keagamaan.

Masyarakat Nagari Tandikat merupakan penganut agama Islam yang taat. Meski demikian, masih sebagian penduduknya masih percaya dan meminta pertolongan kepada makhluk ghaib, berobat ke dukun, tukang upeh, dan mempercayai hal-hal yang bisa mendorong seseorang pada kesyirikan. Hal ini disebabkan oleh beberapa faktor, misalnya faktor ekonomi. Mahalnya biaya berobat ke dokter, membuat masyarakat lebih memilih berobat ke dukun yang relatif lebih murah.

Masyarakat Tandikat segala sesuatu dikaitkan dengan magis. Hal ini terlihat dalam berbagai aktifitas seperti bidang pertanian, perdagangan, dan pengobatan. Di bidang pertanian dikenal beberapa ritual mulai dari proses menanam padi sampai panen. Ritual tersebut diwujudkan dalam bentuk upacara, seperti upacara Manabuab Baniah (tujuan supaya benih mendatangkan hasil yang baik nantinya), upacara Mamintak Ubek Padi (tujuan supaya padi yang mulai berbuah terhindar dari hama dan penyakit), serta upacara Maambiak Padi (upacara sebelum panen), dengan 
mengambil beberapa tangkai padi lalu ditumbuk menjadi beras dan dicampur dengan beras sisa panen sebelumnya, untuk kemudian dimakan bersama dalam acara yang dinamakan Mamakan Hulu Tahun/memakan beras baru. Pemanfaatan hal-hal yang bersifat magis juga ditemui di bidang perdagangan. Ini terlihat dari ritual yang dilakukan pedagang untuk Maureh Lapau atau Maureb Kadai (menyebarkan ramuan yang diminta kepada dukun, di sekeliling tempat usaha) atau dengan memasang jimat dan benda-benda lain yang diberi dukun di tempat usaha tersebut dengan harapan dagangan menjadi laris, begitu juga dalam hal pengobatan. Berbagai ragam penyakit yang menimpa masyarakat dicari penyembuhannya dengan bantuan kekuatan magis (melalui dukun).

Dalam Rozi, aktivitas adat istiadat sebagai salah satu wujud kebudayaan mempunyai arti yang sangat penting bagi kehidupan semua suku bangsa. Adat istiadat direfleksikan melalui unsur religi dalam sistem kepercayaan keagamaan ${ }^{19}$. Upacara keagamaan atau ritus adalah kelakuan keagamaan yang dilaksanakan menurut tata kelakuan yang baku.

\section{Deskripsi Korban Gempa 30 September 2009 di Nagari Tandikat}

Nagari Tandikat merupakan salah satu Nagari yang mengalami dampak cukup parah akibat gempa bumi 30 September 2009, yaitu hampir 90\% bangunan rusak berat, 260 orang meninggal dunia dan 79 orang dinyatakan hilang, hal ini terjadi karena struktur tanah Nagari Tandikat termasuk dalam jenis tanah aluvial, yaitu tanah dari abu letusan gunung yang sangat lembur dan mudah terban atau longsor.

19 Nofiardi, Nofiardi, and Syafwan Rozi, "Penerapan Nilai Toleransi Antar Budaya dalam Pelaksanaan Hukum Kewarisan Islam pada Masyarakat Perbatasan di Rao Pasaman Sumatera Barat", Ijtihad: Jurnal Wacana Hukum Islam dan Kemanusiaan, 17.1, 2017, h. 85-112.
Tiga kampung tertimbun longsor saat gempa menguncang. Akibatnya, ratusan warga diperkirakan tewas tertimbun. Di Kampung Lubuk Laweh, Kampung Sumaniak, dan Kampung Pilian. Tiga dusun itu terletak di Jorong Tandikat, Kecamatan Patamuan, Kabupaten Padang Pariaman. Muslim melaporkan korban-korban di desa di Nagari Tandikat, Kecamatan Patamuan, yang belum dievakuasi. Menurut Muslim, sebanyak 282 orang tertimbun di desa-desa itu. Di desa Lubuak Laweh ada 180 orang, di Pulau Aie 39 orang, Desa Cumanak 50 orang, dan kaki Gunung Tigo 13 orang. Selain Kabupaten Padang Pariaman, Kota Pariaman juga mengalami kerusakan parah. Hingga saat ini ada 207 orang tewas. Belasan ribu rumah hancur.

Di tiga kampung di Nagari Tandikat itu kini yang tampak hanya tanah, pohon dan atap rumah warga. Kampung-kampung itu berada di antara dua bukit. Saat gempa terjadi kedua bukit tersebut longsor dan menyeret rumah warga sekira 300 meter. Longsor juga menimbun rumah beserta warga di kampung tersebut. Menurut warga satu orang korban tewas berjenis kelamin perempuan berhasil dievakuasi, sedangkan suami dan anaknya belum ditemukan. Selain mereka, diperkirakan masih ada ratusan jiwa lainnya tertimbun.

Empat hari setelah musibah gempa $30 \mathrm{~S}$ 09 ini, Pemprov Sumbar, sepakat melakukan pemakaman massal di Nagari Tandikat, Kecamatan Patamuan, Kabupaten Padang Pariaman. Kondisi psikologis korban dapat dideskripsikan dari pernyataan Jawanis 43 tahun berikut ini:

"Bola mata Jawanis, 43, nampak sembab. Raut mukanya kuyu. Sekuyu kain sarung yang dipakainya sewaktu menggali reruntuhan bangunan akibat gempa hebat di Korong Jumanak, Nagari Tandikat, Kecamatan Patamuan, Kabupaten Padang Pariaman. "Lab pai sadonyo Pak. Ndak ado nan tingga lai. 
(Sudah pergi semuanya Pak, tidak ada lagi yang tinggal). Tolonglah kami. Tolonglah kami," kata Jawanis sambil mengais puing-puing bangunan rumahnya yang telah rata dengan tanah, Jumat (2/10) siang".

Waktu itu, di Nagari Tandikat yang memiliki beberapa korong (setingkat dusun, red), di antaranya Jumanak, Gunuang Tigo, Lubuak Laweh, keadaan amat mencabik-cabik relung hati. Sekitar 90 persen rumah penduduk dan fasilitas umum rata dengan tanah. Ratusan orang diperkirakan tertimbun reruntuhan bukit yang mengitari nagari tersebut. Sehingga tak heran, jika saat itu, Nagari Tandikat yang sebelah utara berbatas dengan Kabupaten Agam dan Gunung Tandikat, sebelah selatan Kanagarian Sungai Durian dan Kecamatan Padang Sago, sebelah barat dengan Kecamatan $\mathrm{V}$ Koto, dan sebelah timur berbatas dengan Kecamatan 2 X 11 Enam Lingkung serta Bukit Barisan, benar-benar mirip sebuah "perkampungan mati". Walaupun demikian, Jawanis bersama puluhan warga Tandikat yang masih bertahan hidup, belum mau beranjak meninggalkan kampung mereka yang dalam pameo masyarakat Minangkabau disebut sebagai daerah yang terletak antara wilayah rantau (Pariaman, Padang, dan lainnya) dengan wilayah darek (Luhak Limopuluah Koto, Tanah datar, dan Agam).

"Lun mungkin wak pai dari siko Pak. Kami yakin, masib ado dunsanak nan iduik (Belum mungkin saya pergi dari sini. Saya yakin, masih ada keluarga atau kerabat yang hidup)," kata Jawanis, ketika disarankan menunggu kedatangan tim SAR di posko-posko terdekat. Jawanis memang sangat berharap, orang-orang terdekatnya "selamat" dari maut. Ada enam orang keluarga Juwanis yang tertimbun longsor. "Makonyo, awak cari di dalam rumah ko. Untuang-untuang ado juo nan biduk. (Makanya, saya cari dalam rumah. Mudah-mudahan ada juga yang hidup)," ujar Jawanis, dengan mata berkaca-kaca.
Semangat untuk mencari anggota keluarga yang hilang di Korong Jumanak, Nagari Tandikat, menjelang rencana pemakaman massal di kawasan tersebut, juga diperlihatkan seorang wanita berusia sekitar 24 tahun, asal Lubukalung.

"Rumah mertua saya ada di kampung Jumanak ini. Waktu gempa, beliau di sini. Saya sekarang mencarinya, mudahmudahan beliau selamat," ujar perempuan yang baru datang dari Lubuk Alung itu kepada wartawan.

Sementara itu, di Korong Lubuak Laweh yang merupakan daerah tetangga Korong Jumanak, kondisinya juga terlihat amat memprihatinkan. Tanah dan pasir putih menimbun rumah-rumah warga. Beberapa rumah gadang kebanggaan orang Minang, nampak hanya tinggal gonjongnya saja. Kondisi darurat di Lubuak Laweh belum tersentuh sama-sekali. Namun kemarin, tim SAR bersama warga sudah turun untuk melakukan evakuasi dan pencarian. Hasilnya, ada beberapa jenazah yang bisa ditemukan. Sehingga, meski dikurung sedih, warga dan tim SAR masih semangat melakukan pencarian.

Pada tempat lain, bersamaan dengan semangat warga dan tim SAR untuk melakukan pencarian di Tandikat. Pemprov Sumbar menyepakati pendirian pemakaman massal di kampung tersebut.

"Berdasarkan keputusan rapat hari ini (5/10), kami akan menjadikan wilayah tersebut (Tandikat) sebagai kuburan massal," ujar Kepala Biro Humas Setprov Sumbar Dedek Nuzul Putra, Menurutnya, dalam rapat tersebut, pemerintah akan lebih memfokuskan pencarian pada korban yang kemungkinan masih dapat bertahan hidup dalam reruntuhan bangunan atau yang mengalami cedera. "Juga lokasi ini agak sulit dijangkau dan mereka (korban) sudah tertimbun cukup lama selama 3 hari. Jadi tidak ada kemungkinan hidup," kata dia. Selain itu, lanjut dede, alat-alat berat yang 
dibutuhkan untuk proses evakuasi korban masih sangat minim.

Pemerintah daerah telah meminta bantuan Majelis Ulama Indonesia (MUI) untuk meyakinkan keluarga korban agar rela memakamkan keluarganya secara massal. Namun, pada waktu itu, rencana pendirian pemakaman massal di Tandikat, belum ditanggapi beberapa masyarakat yang berada di ujung utara Kabupaten Padang Pariaman tersebut. Beberapa keluarga korban justru masih berharap, pencarian dapat dilakukan dalam dua hari ke depan.

\section{Program Penanganan Bencana di Nagari Tandikat}

Partisipasi dari pemerintah dan lembaga yang khusus menangani penanggulangan bencana sangat diharapkan dalam memberikan bantuan serta pengetahuan kepada masyarakat tentang mitigasi bencana agar masyarakat bisa lebih siap dalam menghadapi bencana yang sewaktu-waktu akan menimpa mereka. Walaupun demikian partisipasi dari mayarakat tersebut juga sangat mempengaruhi dalam mengurangi dampak bencana, karena masyarakat adalah orang yang akan berhadapan langsung dengan bencana itu sendiri

Di antara bantuan fisik yang telah diberikan kepada korban Bencana Gempa di Nagari Tandikat di antaranya; 1) Bantuan biaya perbaikan rumah sebanyak 15 juta per kepala pada masyarakat terdampak bencana dengan kategori rusak sedang; 2) Bantuan Biaya perbaikan rumah sebanyak 25 Juta per KK bagi keluarga korban dengan kategori rusak berat; 3) Bantuan uang lauk pauk salama 3 bulan@30.000 perhari bagi korban kehilangan rumah; 4) Bantuan daru Genesis dan Qatar Foundation berupa perbaikan rumah bagi korban; 5) Tugu peringatan gempa di daerah ex gempa yaitu Korong Lubuk Laweh dulu yang sekarang luluh lantah tanpa bekas.
Program pemulihan terhadap masyarakat korban gempa Tandikat juga menjadi prioritas Pemerintah Daerah Kabupaten Padang Pariaman, hal ini terbukti dengan masuknya program ini dalam delapan hal rencana kerja prioritas pembangunan Kabupaten Padang Pariaman, di antaranya: 1) Menekan pertambahan penduduk miskin akibat gempa dan sekaligus menekan kemiskinan melalui penyediaan kesempatan kerja pada Program Rekonstruksi Pasca Gempa; 2) Peningkatan Aksebilitas dan kualitas pendidikan serta Rekonstruksi Infrastruktur Pendidikan dan normalisasi proses belajar mengajar/mengajar, serta peningkatan kualitas pelayanan kesehatan serta rekonstruksi infrastruktur kesehatan; 3) Peningkatan ekonomi kerakyatan dan pemberdayaan UMKM melalui perkuatan modal dan rekonstrusi sarana produksi; 4) Rekonstruksi dan peningkatan infrastruktur publik; 5) Peran masyarakat dalam pembangunan nagari; 6) Peningkatan kualitas pelayanan publik dan keterbukaan informasi; 7) Iklim usaha dan jaminan investasi; dan 8) Antisipasi pekat melalui peningkatan kehidupan beragama.

\section{Program Penguatan Nilai-nilai Keagamaan Bagi Masyarakat Korban Bencana Gempa di Nagari Tandikat}

Tindakan-tindakan moral seperti pengiriman bantuan, baik medis, makanan, maupun pakaian merupakan asas-asas nilai yang meneguhnya kita sebagai manusia bermoral. Hal ini menunjukkan bahwa kita berkewajiban untuk menjunjung tindakantindakan suci tersebut yang secara esensial berguna buat diri kita sendiri dan juga orang lain. Di sinilah nilai-nilai moral mendapatkan ruang kehadirannya.

Menurut kepala KUA kecamatan Patamauan Bahri, pada awalnya masyarakat korban gempa yang direlokasi seringkali mengalami trauma karena dalam pikiran 
mereka tidak dapat lagi hidup, namun masih bisa bertahan hingga sekarang dan ada juga keluarga yang hidup sebatang kara. Maka pihak KUA yang bertanggung jawab dalam masalah keagamaan selalu mengirimkan tenaga penyuluh untuk mendampingi mereka.

$$
\text { Kegiatan silaturahmi untuk }
$$
mengumpulkan korban sisa-sisa gempa juga kerap dilakukan agar mereka tidak merasa diabaikan dan selalu mendapatkan pendampingan. TK. Emri Sofiardi sebagai narasumber kegiatan workshop sekalipun putra daerah di sana menyatakan bahwa dalam menghadapi gempa dalam konteks keagamaan ada dua hal yang perlu dilakukan: kegiatan pra gempa dan pasca gempa. Kegiatan pra gempa antara lain adalah: pertama, membentuk keluarga sakinah dalam hal ini adalah menjadikan keluarga sebagai benteng agar terhindar dari gempa dengan cara menjadikan istri, anak, dan lainnya untuk selalu mengerjakan shalat lima waktu serta mendapatkan hasil usaha yang halal. Kedua, mendalami ilmu agama sebagai usaha dalam mendekatkan diri kepada Allah swt. Ketiga, memperbanyak sedekah untuk menjauhkan diri dari musibah.

Sedangkan kegiatan keagamaan yang masih berjalan hingga saat ini, antara lain: wirid yasinan dan tahlilan di setiap Korong di Nagari Tandikat Utara, Tabligh Akbar peringatan gempa $30 \mathrm{~S}$ setiap tahunnya, Penyuluhan Agama oleh pihak KUA Kec. Patamuan, dan beberapa kegiatan lainnya sebagai penunjang pemahaman keagamaan bagi masyarakat korban gempa di Nagari Tandikat.

Sumatera Barat merupakan daerah yang rawan bencana, kerugian yang disebabkan oleh bencana tersebut antara lain: banyaknya manusia yang terluka, hilang terseret arus atau tenggelam dan meninggal dunia; kehilangan harta benda; kerusakan rumah penduduk; sekolah yang tidak berfungsi dan bangunan so- sial-ekonomi lainnya, prasarana yang rusak seperti jalan, jembatan, tanggul sungai, jaringan irigasi, dan prasarana publik lainnya; terganggunya transportasi, serta rusak hingga hilangnya lahan budidaya seperti sawah, tambak dan kolam ikan.

Di samping kerugian yang bersifat material, banjir juga membawa kerugian non material, antara lain kerawanan sosial, wabah penyakit, menurunnya kenyamanan lingkungan, serta menurunnya kesejahteraan masyarakat akibat kegiatan perekonomian mereka terhambat. Kita memerlukan sikap bijak dalam menghadapi bencana banjir dan bencana lainnya yang kerap melanda. Sikap bijak itu merupakan bagian integral dari jati diri kita sebagai mahluk religius dan memiliki daya intelektualitas.

Orang dengan kadar religiusitas tinggi, memiliki pemahaman bahwa bencana adalah takdir Tuhan, bagian dari Hukum Alam, Sunnatullah yang tidak bisa dirubah oleh manusia. Selanjutnya, orang dengan kadar religiusitas dan intelektualitas yang tinggi, memiliki pemahaman bahwa bencana bukan takdir Tuhan an sich, melainkan misteri dari Tuhan yang manusia diberi kewenangan olehNya untuk mengungkapkannya.

Itulah antara lain argumentasi keagamaan untuk menjawab pertanyaan; mengapa Tuhan menjadikan manusia sebagai khalifahnya di bumi ini. Ada sebagian urusan Tuhan yang diserahkan-Nya kepada manusia, yang dalam pemenuhannya memerlukan kerja keras dalam konteks keseimbangan antara aspek religiusitas dengan aspek intelektualitasnya. Hari ini, menjelaskan bencana tidak lagi efektif hanya dari perspektif dogma dan ajaran agama. Ia memerlukan keterlibatan ilmu pengetahuan, sains dan teknologi yang merupakan hasil dari imajinasi dan observasi ilmiah sebagai cermin ketinggian intelektualitas. 
Penjelasan tentang bencana tak boleh lagi berhenti pada pernyataan bahwa "bencana adalah murka Tuhan", bahwa "Tuhan sedang menurunkan azabnya karena manusia melanggar perintah-Nya”. Pernyataan itu benar dan sama sekali tidak mengurangi kemahaperkasaan Tuhan. Tapi pernyatan itu mendistorsi sifat Maha Pengasih, Maha Penyayang, Maha Memelihara yang manusia memiliki hak untuk mendapatkannya dari Tuhan, termasuk dalam situasi terjadi bencana. Karena satu hal; bencana-yang kadang diidentikkan dengan musibah cobaan hingga azab- tidak terjadi dan menimpa hanya kepada para pendosa, melainkan juga kepada kaum beriman yang memiliki akhlak dan kebajikan.

Memiliki kesadaran dan pemahaman bahwa bencana adalah Takdir (ketentuan dan ketetepan dalam rencana Tuhan), adalah hal yang paling utama karena kita adalah masyarakat beragama dan berketuhanan. Penting untuk memegang teguh kesadaran bahwa dalam keadaan terjadi bencana, Tuhan hadir, ada dan selalu bersama kita dan pasti mendengar lalu mengabulkan permintaan kita. Dan melalui agama, Tuhan telah menyediakan panduan untuk mengambil tindakan dalam menyikapi bencana.

Di satu sisi, kesadaran itu penting untuk menepis kepasrahan total terhadap Tuhan yang tanpa upaya apapun dalam menghadapi bencana. Juga penting untuk mengelaborasi makan takdir agar tidak menjerat dan membelenggu karena pemahaman seperti itu bertentangan dengan ajakan Tuhan untuk mendinamisasi diri dalam upaya yang kongkrit untuk sebuah perubahan dalam kehidupan.

Di sisi lain, kesadaran itu diperlukan untuk mengerem laju sekularisasi pemikiran dan pemahaman tentang kebencanaan, yaitu pemikiran dan pengetahuan yang meninggalkan ruang agama dan ketuhanan, mendewakan intelektualitas dan kedigdayaan sains dan teknologi, yang menempatkan manusia sebagai penguasa bumi yang rakus, merasa memiliki kebebasan dalam memperlakukan alam secara tidak bertanggung jawab, sehingga menimbulkan terjadinya bencana.

Tindakan-tindakan moral seperti pengiriman bantuan, baik medis, makanan, maupun pakaian merupakan asas-asas nilai yang meneguhnya kita sebagai manusia bermoral. Hal ini menunjukkan bahwa kita berkewajiban untuk menjunjung tindakantindakan suci tersebut yang secara esensial berguna buat diri kita sendiri dan juga orang lain. Di sinilah nilai-nilai moral mendapatkan ruang kehadirannya.

Menurut Sabar, selaku Wali Nagari Tandikat Utara, kejadian gempa yang melanda nagari Tandikat dan menghilangkan harta benda serta memisahkan antara keluarganya yang telah berlangsung lebih dari enam tahun telah menjadi pelajaran yang mendalam bagi warga setempat serta masyarakat lainnya bahwa hal ini harus dikembalikan kepada penyadaran agama. Agama memiliki peran untuk mengembalikan segala sesuatunya kepada Allah swt. Manusia tidak memiliki daya dan upaya untuk mencegahnya, maka pendekatan diri kepada Allah adalah jalan agar manusia tidak berputus asa.

Aspek religiusitas (keagamaan) sangat menentukan cepatnya pemulihan dampak psikososial korban. Bila aspek religiusitas tinggi, keluarga korban lebih cepat menerima bencana sebagai suatu cobaan dan ada hikmah yang bisa diambil dari kejadian itu. Orang seperti ini akan mampu mengumpulkan energi yang ada untuk menata kehidupan selanjutnya. Tapi, jika masih trauma, maka akan mengganggu aktivitas hidupnya sehari-hari. Energinya lebih banyak digunakan untuk memikirkan orang yang hilang.

Untuk menanganinya, tidak cukup hanya dengan konseling, tapi perlu pendampingan 
terus menerus. Cepat tidaknya proses penyembuhan, sangat tergantung kepada pribadinya dan pengaruh nilai-nilai agama dalam masyarakatnya. Tidak semua orang yang menjadi korban bencana akan mengalami trauma yang berujung pada gangguan mental. Ada yang lambat dan ada yang cepat. Seperti remaja yang putus cinta pertama, ada yang cepat melupakan dan mencari lagi pasangan baru, tetapi ada juga yang trauma sehingga memutuskan untuk tidak menikah. Inilah karakteristik personality tiap manusia. Masingmasing mempunyai karakteristik berbeda karena penyebabnya berbeda, walaupun ada unsur-unsur yang sama. Aspek emosi, afeksi, dan kognisi serta perilaku korban-korban pun berbeda. Dari ketiganya itu akan berbeda bila dilihat dari kasus atau jenis bencana yang menimpa.

Biasanya, dalam beberapa pekan, orang sangat ingin mendapatkan informasi atau kejelasan mengenai anggota keluarga, ingin cepat tahu bagaimana kondisinya dan berharap masih bisa diselamatkan. Ini juga bisa disebut trauma, suatu kondisi kejiwaan yang sangat membekas. Sedangkan, post traumatic adalah kejadian yang sangat membekas dan memiliki sisa. Pengalaman sisa yang membayanginya itu mempengaruhi residu. Selanjutnya, residu itu memengaruhi emosi (afeksi) dan kognisi disertai dengan tingkah laku yang berbeda.

Dengan afeksi itu, korban biasanya masih larut dan sering menangis. Ia masih membayangkan sehingga tingkah lakunya sangat terpengaruhi oleh kondisi jiwanya. Pada situasi ini, korban harus bisa keluar dari kondisi psikis seperti itu. Korban dalam pendampingan harus diarahkan untuk menerima realita hidup dengan harapan bisa menjadi lebih baik dalam menjalani kehidupan barunya. Namun, dalam penerimaanya akan berbeda, bisa positif bisa negatif. Korban yang tidak bisa menerima secara positif, nanti akan menganggap ada suara-suara yang memanggilnya. Akhirnya, dia pergi ke mana saja sesuai dengan yang bayangkannya. Kadang, untuk menghilangkan kondisi atau rasa sakit, tidak jarang mulai menggunakan obat-obat anti depresi. Asalnya tidak merokok menjadi perokok, bahkan ada yang menggunakan narkotika.

Sebenarnya, kalau melihat sekilas korban bencana sudah nampak. Tapi ini harus dilakukan dengan pengukuran dan pemeriksaan. Pemeriksaan itu bisa dilihat dari berbagai aspek, misalnya tekanan darah. Bila tinggi, itu salah satu indikasi. Dari aspek mental dapat diukur dalam hal konsentrasi dan kestabilan emosi. Atau, apakah korban-korban itu berada pada tingkat yang ringan, sedang, atau kondisinya berat? Bila berat, harus segera dirujuk. Untuk kondisi sedang pun harus ditangani serius.

\section{Kesimpulan}

Aspek religiusitas atau nilai-nilai keagamaan seperti kepasrahan, tidak menyerah pada takdir serta terus bekerja keras sangat menentukan cepatnya pemulihan dampak psiko-sosial korban. Bila aspek religiusitas tinggi, keluarga korban lebih cepat menerima bencana sebagai suatu cobaan dan ada hikmah yang bisa diambil dari kejadian itu. Orang seperti ini akan mampu mengumpulkan energi yang ada untuk menata kehidupan selanjutnya. Tapi, jika masih trauma, maka akan mengganggu aktivitas hidupnya sehari-hari. Energinya lebih banyak digunakan untuk memikirkan orang yang hilang

Bantuan penanganan bencana seperti pengiriman bantuan, baik medis, makanan, maupun pakaian merupakan asas-asas nilai yang meneguhnya kita sebagai manusia bermoral. Hal ini menunjukkan bahwa kita berkewajiban untuk menjunjung tindakantindakan suci tersebut yang secara esensial berguna buat diri kita sendiri dan juga orang lain. Di sinilah nilai-nilai moral mendapatkan ruang kehadirannya. 
Persoalan semacam ini telah dan selalu menjadi agenda serius bagi para pencari makna hidup dari zaman ke zaman, karenanya ketika seseorang memasuki wilayah perburuan yang juga dimasuki oleh sekian banyak filosof dan mistikus yang datang dari berbagai kelompok sosial keagamaan dan sejarah.

\section{Daftar Pustaka}

\section{Buku Teks}

Tim IDEP, Panduan Umum Penanggulangan Bencana Berbasis Masyarakat (Bali, Yayasan IDEP, 2007).

Tim Penyusun, Hasil Simposium Nasional Kedua Manajemen Resiko Bencana Berbasis Masyarakat Mencari Jadi Diri Bangsa Indonesia, Hotel Sofyani, Cikini Jakarta, 12-13 April 2006.

Tim Penyusun, Panduan Pengenalan Karakteristik Bencana dan Upaya Mitigasinya di Indonesia (Jakarta: Tim Bakornas BP, 2007).

Jalaluddin, Psikologi Agama," Memahami Perilaku Keagamaan Dengan Mengaplikasikan Prinsip-Prinsip Psikologi" RajaGrafindo Persada, 2007).

Sadily, Hasan, Sosiologi Untuk Masyarakat Indonesia (Jakarta: PT. Rineka Cipta,1993).

Berger, Peter L., Langit Suci, Agama Sebagai Realitas Sosial (Jakarta: LP3ES, 1991).

Prasetya, Tiar (ed.), Gempa Bumi: Ciri dan Cara Menanggulanginya (Yogyakarta: Gita Nagari, 2006).

Abdullah, Irwan, "Dialektika Nature, Kultur dan Struktur: Analisis Konteks, Proses dan Ranah dalam Konstruksi Bencana”, Makalah disampaikan dalam Pidato Pengukuhan Guru Besar Antropologi di UGM Tanggal 13 November 2006.

Don, L. \& Florence Leet, Gempa Bumi, Penjelasan Ilmiah \& Sederhana, Proses, Tanda- Tanda Akan Terjadinya, Serta Antisipasi Dampak."(Yogyakarta: Kreasi Wacana, 2006).

\section{Jurnal}

Chester, D. K., "Theology and Disaster Studies: The Need for Dialogue", Journal of Volcanology and Geothermal Research, Vol. 146, No. 4, 2005.

Effendi, Nusyirwan, "Bencana: Pengalaman dan Nilai Budaya Orang Minangkabau", Jurnal Masyarakat Indonesia LIPI, Vol. 2, No. 2, 2007.

Gaillard, J. C. and P. Texier, "Religions, Natural Hazards, and Disasters: An Introduction", Religion, Vol. 40, 2010.

Ha, Kyoo-Man, “The Role of Religious Beliefs and Institutions in Disaster Management: A Case Study", Religions, Vol. 6, 2015.

Nofiardi, Nofiardi, and Syafwan Rozi, "Penerapan Nilai Toleransi Antar Budaya dalam Pelaksanaan Hukum Kewarisan Islam pada Masyarakat Perbatasan di Rao Pasaman Sumatera Barat", Ijtihad: Jurnal Wacana Hukum Islam dan Kemanusiaan, 17.1, 2017.

Pratibha, Akhand and Akhand Archna, "At the Whim of Nature "Natural Disasters": Causes and Prevention", Social Issues and Environmental Problems, Vol. 3, No. 9, 2015.

Rozi, Syafwan, "Local Wisdom and Natural Disaster in West Sumatera", ElHarakah, Vol. 19, No. 1, 2017.

Solihu, Abdul Kabir Hussain, "Making Sense of Natural Disasters: An Islamic Hermeneutics of Malevolent Phenomena in Nature and Its Implication for Sustainable Development", The American Journal of Islamic Social Sciences, Vol. 24, No. 1, 2007.

Steinberg, Theodore, "What Is a Natural Disaster?," Literature and Medicine, Vol. 15, No. 1, 1996. 